CONTROL OF OXIDATION POTENTIAL. FOR

BASALT REPOSITORY SIMULATION TESTS

by

Carol M. Jantzen and George G. Wicks

E. I. du Pont de Nemours and Company

Savannah River Laboratory

Aiken, South Carolina 29808

For presentation and publication in the proceedings

1984 Annual Meeting of the Materials Research Society

Boston, Massachusetts

November 26-30, 1984

\title{
SRL \\ RECORD COPY
}

This paper was prepared in connection with work done under Contract No. DE-AC09-76SR00001 with the U.S. Department of Energy. By acceptance of this paper, the publisher and/or recipient acknowledges the U.S. Government's right to retain a nonexclusive, royalty-free license in and to any copyright covering this paper, along with the right to reproduce and to authorize others to reproduce all or part of the copyrighted paper. 
This document was prepared in conjunction with work accomplished under Contract No.

DE-AC09-76SR00001 with the U.S. Department of Energy.

\section{DISCLAIMER}

This report was prepared as an account of work sponsored by an agency of the United States Government. Neither the United States Government nor any agency thereof, nor any of their employees, makes any warranty, express or implied, or assumes any legal liability or responsibility for the accuracy, completeness, or usefulness of any information, apparatus, product or process disclosed, or represents that its use would not infringe privately owned rights. Reference herein to any specific commercial product, process or service by trade name, trademark, manufacturer, or otherwise does not necessarily constitute or imply its endorsement, recommendation, or favoring by the United States Government or any agency

thereof. The views and opinions of authors expressed herein do not necessarily state or reflect those of the United States Government or any agency thereof.

This report has been reproduced directly from the best available copy.

Available for sale to the public, in paper, from: U.S. Department of Commerce, National Technical Information Service, 5285 Port Royal Road, Springfield, VA 22161, phone: (800)

553-6847, fax: (703) 605-6900, email: orders@ntis.fedworld.gov online ordering: http://www.ntis.gov/ordering.htm

Available electronically at http://www.doe.gov/bridge

Available for a processing fee to U.S. Department of Energy and its contractors, in paper, from: U.S. Department of Energy, Office of Scientific and Technical Information, P.O. Box 62, Oak Ridge, TN 37831-0062, phone: (865 ) 576-8401, fax: (865) 576-5728, email: reports@ adonis.osti.gov 
CAROL M. JANTZEN AND GEORGE G. WICKS

E. I. du Pont de Nemours and Company, Savannah River Laboratory, Aiken, South Carolina 29808

\section{ABSTRACT}

Borosilicate waste glass durability in simulated repository environments can be assessed by use of static tests in leach vessels fabricated of the representative geomedia. Control of the oxidation potential during the test simulates a basalt repository environment. Under very anoxic conditions (i.e. at negative Eh values), the interactions between basalt and SRP waste glass in silica-saturated basaltic groundwaters are the same as those of basalt and groundwater when no waste glass is present. The lack of significant leaching of ions from the waste glass and the lack of any significant changes in either the leached surfaces of glass or basalt under anoxic conditions suggests that the components of this system are at equilibrium when oxygen is absent.

\section{INTRODUCTION}

Radioactive waste glasses contain many elements which are redox active, i.e. can occur in more than one redox state. The valence state of an ion can be important in determining its equilibrium solubility and its rate of release from the waste form. Moreover, the adsorption and migration of multivalent elements in geologic media are highly dependent upon the redox states of elements dissolved in the groundwater. Because long-lived hazardous nuclides such as TC, Am, or Np are less soluble in the reduced state, reducing groundwaters could limit the release of these species.

of the geologic formations considered for high-level waste repositories in the United States (tuff, salt, and basalt), the basalt groundwater is expected to be the most strongly reducing with an oxidation potential, or Eh, of $-0.40+0.05 \mathrm{~V}[1,2]$. Waste form leach tests have not, to date, addressed leaching under low-Eh repository conditions $[3,4]$. Thus, methods to control the Eh in the laboratory without the use of chemical additives were developed $[5,6]$ to accurately determine glass performance in a basalt repository environment.

In this study, the results of the first set of static leach tests of defense waste glass under conditions specific to a nuclear waste repository in basalt are presented. Durability of defense waste glass under conditions relevant to a basalt repository can be assessed accurately only when interactions between waste glass, stainless steel, and basalt rock are examined in simulated groundwater in the absence of oxygen.

\section{EXPER IMENTAL}

Equilibration of simulated groundwaters with crushed rock under deoxygenated conditions provides an anoxic, low Eh solution to be used as a leachant for testing waste package component interactions [6]. The deoxygenated experiments are contained in a glove box continuously purged with 99.999\% argon (Figure 1). The iron-bearing species in basalt yield redoxactive species in solution which give stable Eh measurements. Because the 
$\mathrm{Fe}^{2+} / \mathrm{Fe}^{3+}$ redox couple dominates the controlled laboratory experiment, it was assumed that the electrode measures this redox couple $[5,6]$. Experimentation in a controlled laboratory can thus achieve the anoxic values calculated for crystalline repositories but not measured in the field due to problems with oxygen contamination.

Simulated basaltic groundwater [7] was equilibrated with crushed basalt. Crushed Umtanum basalt had previously been found $[5,6]$ to be most effective at setting or controlling the Eh at negative values and it is representative of the candidate repository Grande Ronde formations. Basalt $S A / V$ ratios of approximately $10 \mathrm{~cm}^{-1}$ at $60^{\circ} \mathrm{C}$ are achieved in approximately 90 hours with deoxygenated GR-4 groundwater. The $E$ h and $\mathrm{PH}$ of the rock-equilibrated solution was monitored in-situ. Replicate experiments with deoxygenated GR-4 groundwater and crushed Grande Ronde basalts confirmed that $E h$ values of -0.34 to $-0.40 \mathrm{~V}$ at $\mathrm{pH}$ values of $9-10 \mathrm{can}$ be achieved repeatedly. These values compare favorably to the Eh values of $-0.40 \mathrm{~V}$ at $\mathrm{pH} 9.1+0.5 \mathrm{calculated}$ for a basalt repository at $70^{\circ} \mathrm{C}$ [2].

Equilibration of GR-4 with crushed Umtanum basalt (SA/V approximately $10 \mathrm{~cm}^{-1}$ ) at $60^{\circ} \mathrm{C}$ achieved an $\mathrm{Eh}$ of $-0.34 \mathrm{~V}$ at a pH of approximately 10 after 90 hours residence time. This equilibrated groundwater was used to evaluate the interactions between basalt and simulated SRP waste glass under anoxic, static (MCC-1) conditions. Three rock cup vessels [8] inside Teflon leach vessels were filled with pretreated GR-4 and kept in an oven at $90^{\circ} \mathrm{C}$ in the argon glovebox (Figure 1 ). Two of the rock cup vessels contained simulated SRL-165 waste glass polished to a $600 \mathrm{grit}$ finish. One rock cup vessel did not contain glass and was used as an anoxic standard or blank. Two other rock vessels were filled in the environmental chamber and sealed in Parr bombs. These were removed from the environmental chamber and placed in an oven in air at $90^{\circ} \mathrm{C}$. Likewise, two more rock cup vessels inside Teflon leach vessels were filled inside the chamber and subsequently placed in a $90^{\circ} \mathrm{C}$ oven in air (Figure 1). The glass $S A / V$ was $0.1 \mathrm{~cm}^{-1}$ and the test duration was 28 days.

Solutions were analyzed in triplicate by inductively coupled plasma (ICP), ion chromatography (IC), atomic absorption (AA), and a Scintrex UA-3 analyzer. The leachates were analyzed acidified and nonacidified but not filtered. The glass and rock surfaces, and precipitates, were examined by scanning electron microscopy and by electron microprobe.

\section{INTERACTIONS BETWEEN SRL-165 WASTE GLASS, BASALT, AND SIMULATED GROUNDWATER}

Interactions between defense waste glass and basalt in contact with pre-equilibrated low Eh(-0.34V) GR-4 simulated groundwater vary as a function of the final oxidation potential (Eh) of the solution. Of the seven tests described above, the one anoxic test that contained only basalt and simulated groundwater was used as an anoxic standard or blank in order to determine the background concentration of elements leaching out of the rock when no waste glass was present.

In six of the seven tests, negative oxidation potentials were successfully maintained for 28 days inside the rock leaching vessels (Table I).

The annular space outside the rock cup was completely oxidized ( $E \mathrm{~h}=+0.4 \mathrm{~V}$ ) in the test at $90^{\circ} \mathrm{C}$ in air. Oxidation of the solution in the annular space was anticipated for the test at $90^{\circ} \mathrm{C}$ in air as the Teflon outer leach vessels are not airtight. The oxidation state of the solution in the annular space in the vessels in the environmental chamber remained anoxic $(E h=-0.27$ to $-0.29 \mathrm{~V})$. The Parr bombs do not have an annular space and so no similar evaluation could be made.

The tests carried out in the environmental chamber were the most successful at maintaining the low Eh conditions inside the rock vessels (Table I). None of the solutions inside the rock cup ever reached the 
oxidation potential of the solution saturated with air (Eh $\geq+0.4 \mathrm{~V}$ ). All of the solutions changed from an initial pH of 10.15 at ambient temperature to a final pH near neutral regardless of whether waste glass was present or not.

Analyses of the groundwater solution inside the rock cup (in contact with glass) can be correlated with the final Eh of the solution (Figures 2-3). Anoxic conditions decrease the concentration of redox elements in solution (Figure 2 ). The concentrations under very reducing conditions are the same as the blank, e.g. when no glass is present. The scatter in the uranium data is due to the low concentrations present. At these low concentrations, errors of $+10 \mathrm{ppb}$ are expected. Anoxic conditions also appear to decrease the release of the alkali indicator element lithium from the glass (Figure 3). For the glass matrix elements silicon and boron (Figure 3), there is little or no apparent release of these elements within experimental error. Note that for boron the entire span of the experimental data is only $1 \mathrm{ppm}$ and no trends $\mathrm{c}$ an be delineated. There is no change in the measured concentration of these elements when acidified according to MCC-1 procedures [9]. Samples re-analyzed at 1 month intervals after acidification showed no change. Acidification was not slowly dissolving any colloidal material in the leachate.

The normalized mass losses for $U, B$, and $L i$ at an oxidation potential of $-0.4 \mathrm{~V}$ after 28 days are $0.19,0.23$, and $0.22 \mathrm{~g} / \mathrm{m}^{2}$, respectively. In terms of an annular release rate, these values are $5^{-} \times 10^{-7}, 6.0 \times 10^{-7}$, and $6.0 \times 10^{-7} \mathrm{yr}^{-1}$.

The glass surfaces which were toward the top of the leach vessel were covered with a fine grey precipitate. The lower surfaces did not have any precipitate cover. Examination of the upper surfaces by electron microprobe and scanning electron microscopy revealed that this precipitate was only loosely attached. In areas where the precipitate surface was broken away, the original polishing scratches in the glass surface from sample preparation before leaching could be observed. The precipitate was found to be rich in $\mathrm{Ca}, \mathrm{Mg}, \mathrm{Al}$, and $\mathrm{Si}$ suggesting that it was suspended particles of $\mathrm{Na0} .33 \mathrm{Ca0} .66 \mathrm{AI} 1.8 \mathrm{Si}_{2.208}$ that was in the pre-equilibrated groundwater as reported previousiy [6]. No glass leached layer was observed by electron microprobe (minimum resolution $0.2 \mu \mathrm{m}$ ).

Examination of the lower leached surfaces (leached under the more oxidizing conditions) by electron microprobe and scanning electron microscopy showed some etching of the original polishing marks. There was no evidence of etching or leaching in the samples in the very anoxic groundwater in 28 days. In cross section, no leached layer was observed with the electron microprobe.

Lastly, the surfaces of the rock leach vessel were examined by scanning electron microscopy. In the more oxidized case, the interstitial glass in the rock had been etched away and some fine need le shaped phase redeposited. In the anoxic groundwaters, there was little or no deterioration nor any reprecipitation on the rock surfaces. Energy dispersive $x-r a y$ analys is of the oxic and anoxic rock surfaces showed that the surface exposed to oxygenated groundwater was enriched in iron.

\section{INTERACTIONS BETWEEN SRL-165 WASTE GLASS AND SIMULATED GROUNDWATER}

Since no significant interaction occurred between the waste glass, basalt rock, and simulated groundwater when oxygen was absent, the components of the system appeared to be at equilibrium. SRL waste glasses contain approximately $12 \mathrm{wt} \%$ iron comparable to basalt. The SRL glass has a ratio of ferrous to ferric iron $\left(\mathrm{Fe}^{2+} / \mathrm{Fe}^{3+}\right.$ ) of approximately 0.48 [10], while basalts are more enriched in ferrous iron. The results for equilibration of 
GR-4 groundwater with rock were, therefore, compared to GR-4 groundwater interactions with SRL-165 waste glass (Figure 4). Eh-pH values for GR-4 groundwater and basalt are $-0.34 \mathrm{~V}$ at approximately $10 \mathrm{pH}$ whi le the values for interaction of GR-4 groundwater and waste glass are - $0.39 \mathrm{~V}$ at approximately $9.5 \mathrm{pH}$ at $60-65^{\circ} \mathrm{C}$ (Figure 4 ). These values represent the calculated equilibrium Eh-pH for a basalt repository at $70^{\circ} \mathrm{C}$ [2] which is superimposed on Figure 4.

\section{CONCLUSIONS}

Basalt repositories are expected to be mildly to strongly reducing and the presence of free oxygen will be limited. Redox-active solids such as crushed basalt can be used to control the oxidation potential of waste glass leachants during laboratory experimentation. Iron present in the solution from the basalt is in both the ferrous and ferric states which readily allows stable and reproducible measurements [6].

The interactions between basalt and waste glass in simulated basalt repository groundwater (GR-4) demonstrates that solution concentrations under very anoxic conditions were nearly the same as those of basalt and groundwater when no waste glass was present. The lack of significant changes in solution concentrations and the lack of any significant changes in the glass surfaces after leaching under low-Eh conditions suggest that minimal leaching has occurred in 28 days. The basalt rock surfaces also remained unaltered under these conditions in contrast to the results obtained with oxygenated groundwaters.

No significant interactions occur among the rock, the glass, and the solution when oxygen is absent. This implies that under deoxygenated conditions the components of this system are nearly at equilibrium. This is supported by the findings that crushed SRL-165 waste glass alone in deoxygenated basaltic groundwater imparts the same Eh and $\mathrm{pH}$ to the solution as crushed basalt.

\section{ACKNOWLEDGMENT}

The information contained in this article was developed during the course of work under Contract No. DE-AC09-76SR00001 with the U.S. Department of Energy. 


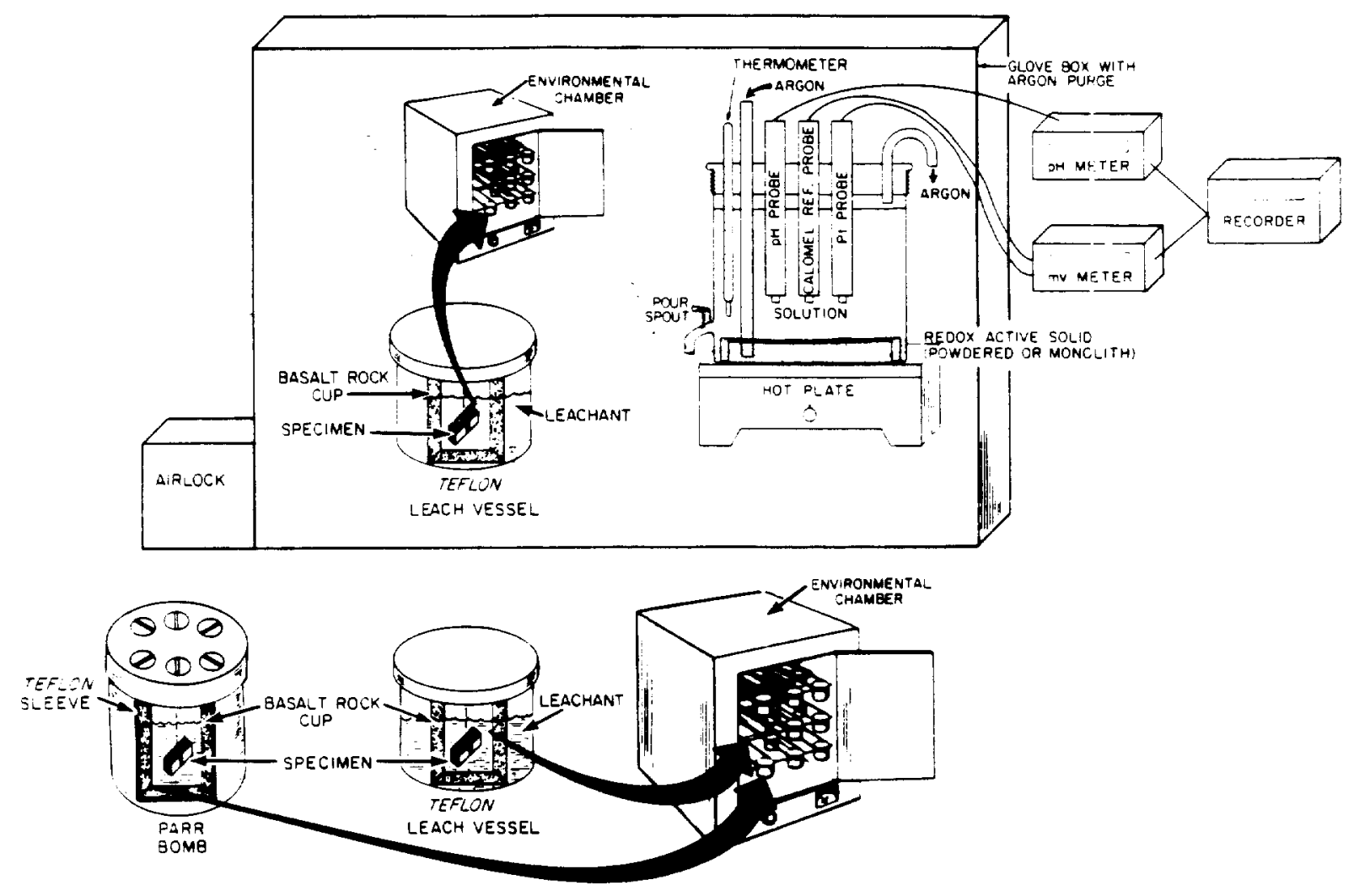

FIGURE 1. Experimental design. All leach vessels including the Parr bombs filled inside glove box. 

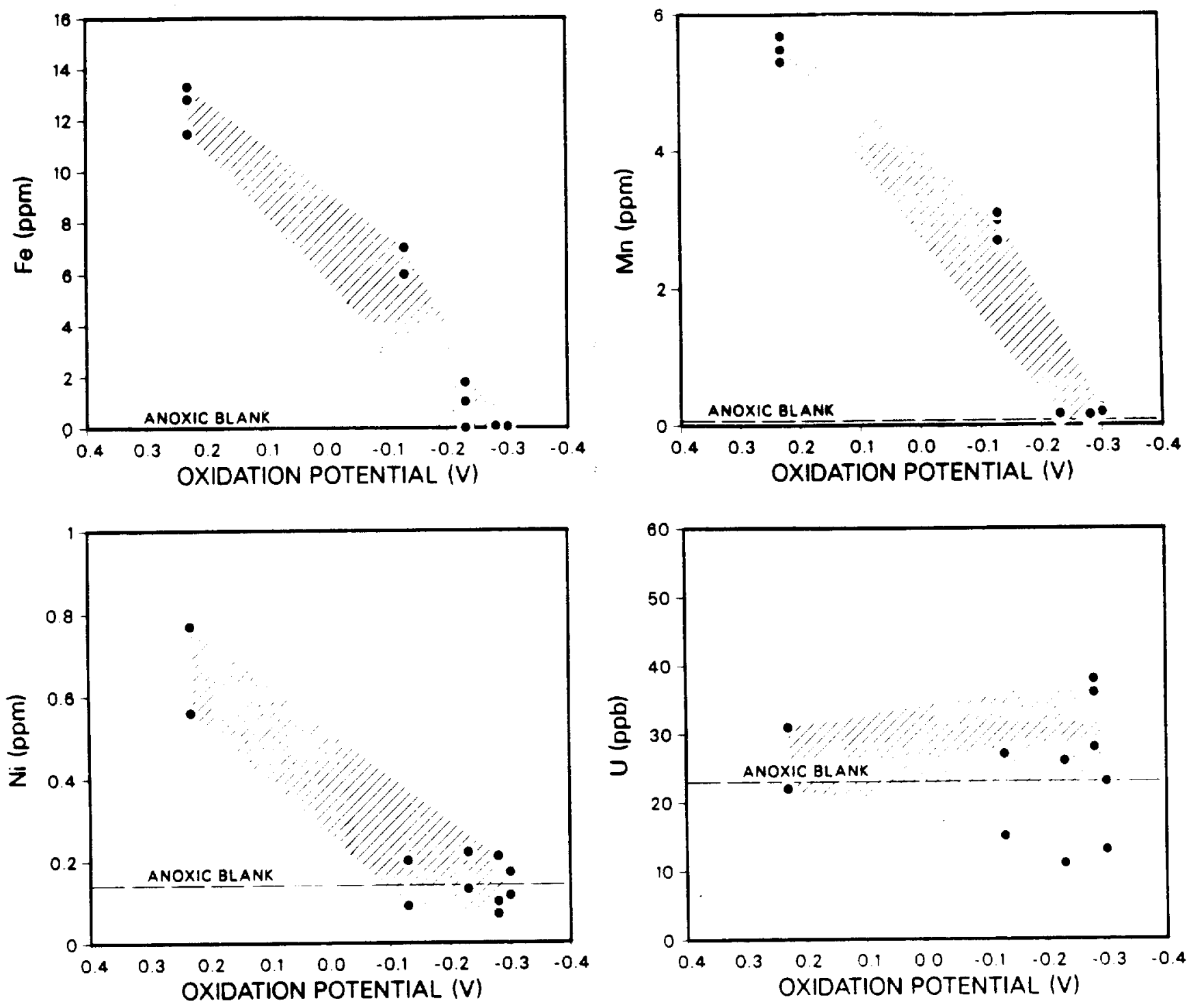

FIGURE 2. Concentrations of redox sensitive elements leached from the glass as a function of oxidation potential, Eh. 

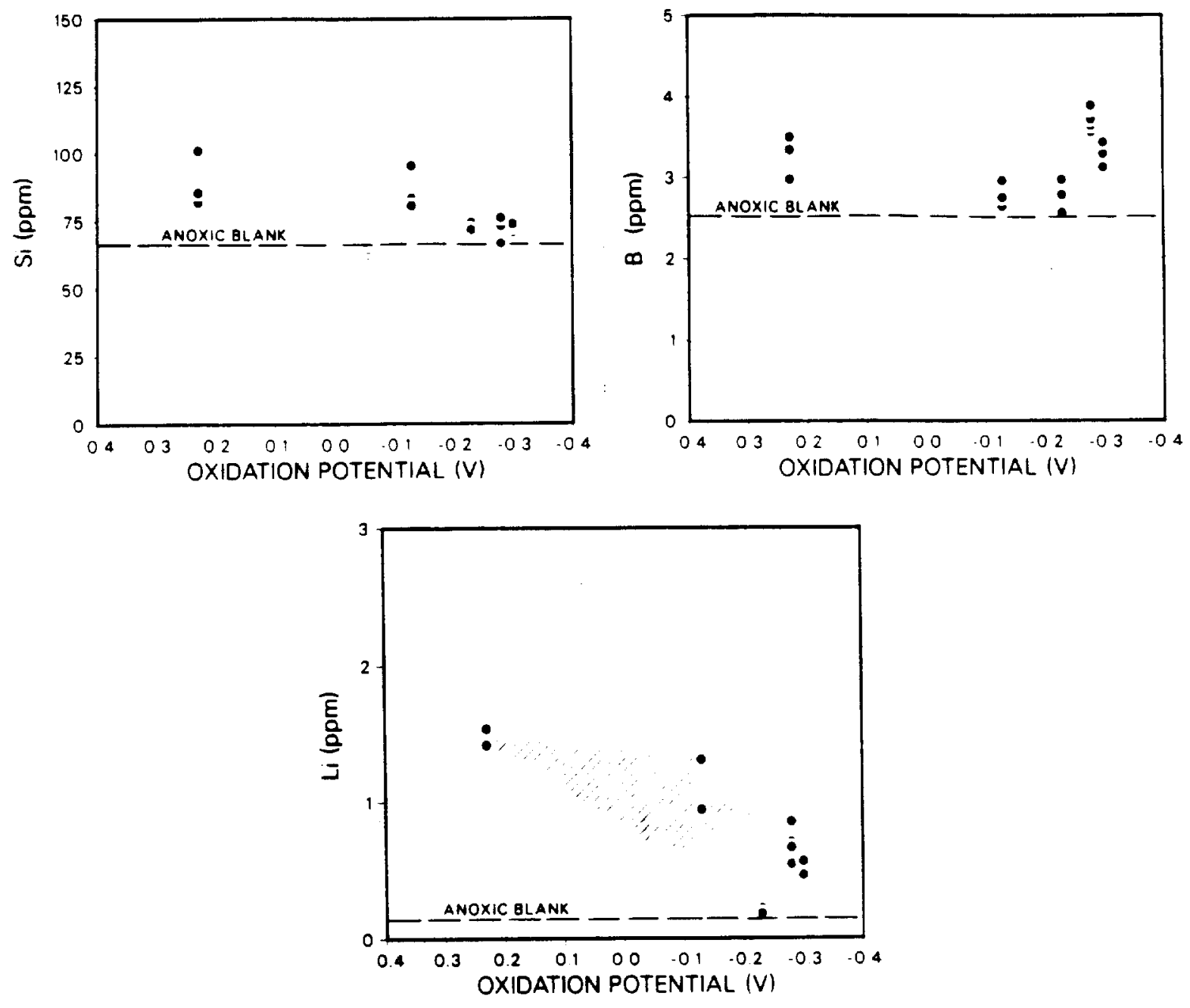

FIGURE 3. Concentrations of glass matrix elements and the alkali indicator element $\mathrm{Li}$ which is leached from the glass as a function of oxidation potential, Eh. 
BASALT/GR-4 GROUNDWATER

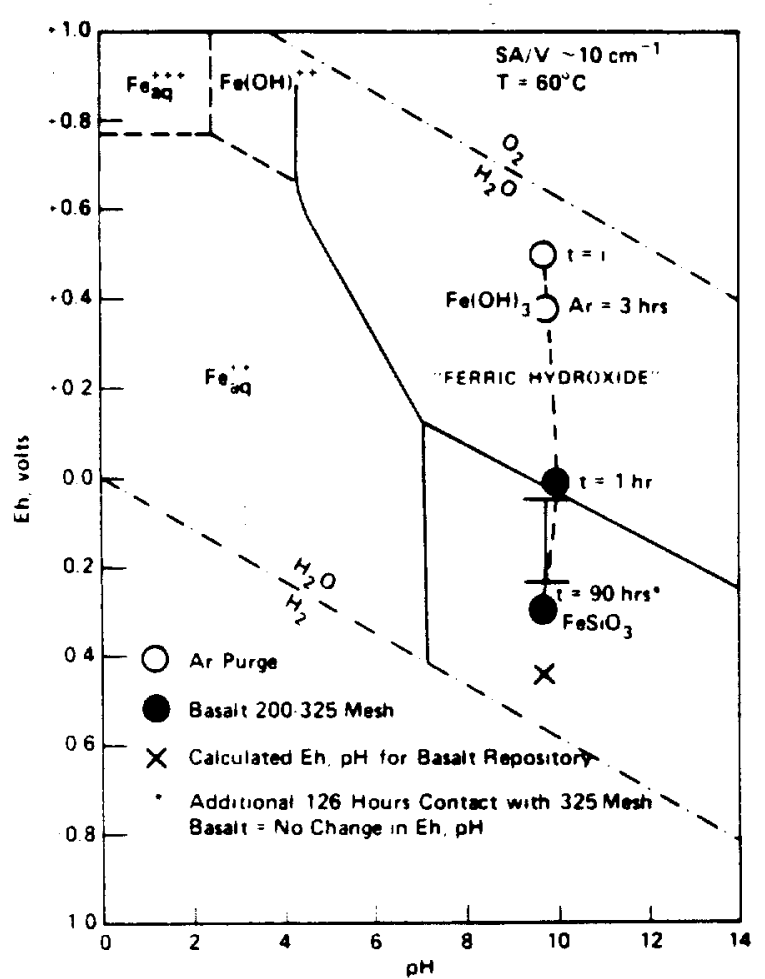

SRL 165 GLASS/GR-4 GROUNDWATER

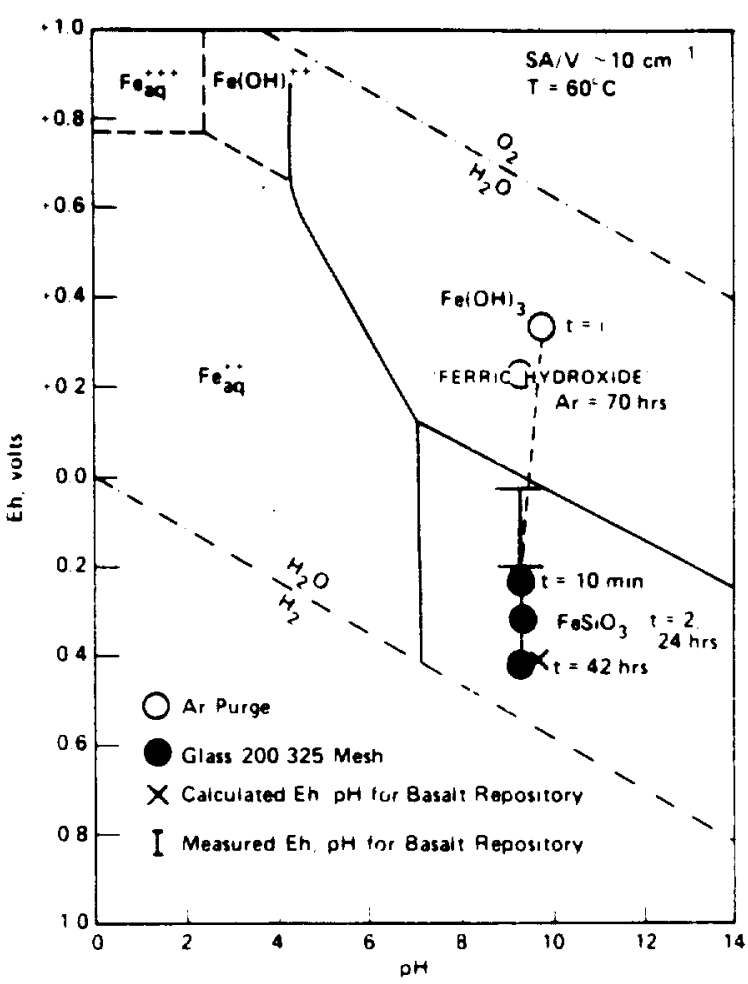

FIGURE 4. The final Eh-pH values achieved when crushed Umtanum basalt or SRL-165 waste glass is reacted with GR-4 groundwater. The vertical bar represents the range of Eh values actually measured for the BWIP repository [11] while the $X$ represents the calculated $\mathrm{Eh}$ and $\mathrm{pH}$ values $[2]$. 
TABLE I. Eh AND PH VALUES FOR REPOSITORY SIMULATION TESTS IN BASALT

\begin{tabular}{|c|c|c|c|c|c|c|c|}
\hline & GLASS & SOLL & $10 \mathrm{~N}$ & IN ROCK & CUP & $\begin{array}{r}\text { IN AN } \\
\text { SP }\end{array}$ & $\begin{array}{l}\text { ULAR } \\
\text { CE }\end{array}$ \\
\hline TEST & PRESENT & Ehi & pHi & Ehf & $\mathrm{pHf}$ & Ehf & $\mathrm{pHf}$ \\
\hline OVEN IN & YES & -0.33 & 10.15 & $+0.23^{*}$ & 6.03 & +0.4 & 7.50 \\
\hline OXYGENATED & YES & -0.33 & 10.15 & $-0.13^{* *}$ & 5.86 & +0.39 & 7.50 \\
\hline ATMOSPHERE & & & & & & & \\
\hline PARR & YES & -0.33 & 10.15 & -0.28 & 6.92 & & \\
\hline BOMBS & YES & -0.33 & 10.15 & -0.23 & 7.25 & & \\
\hline OVEN IN & YES & -0.33 & 10.15 & -0.30 & 6.85 & -0.28 & 7.36 \\
\hline ENVIRONMENTAL & YES & -0.33 & 10.15 & -0.28 & 6.80 & -0.29 & 7.56 \\
\hline CHAMBER & No & -0.33 & 10.15 & -0.27 & 7.11 & -0.27 & 7.60 \\
\hline
\end{tabular}

* this sample was tilted and there may have been some in-leakage of WATER FROM THE ANNULAR SPACE INTO THE ROCK CUP.

* self sealing of the rock cup to its lid was observed in this test.

t ALL MEASUREMENTS AT $25^{\circ} \mathrm{C}$. 


\section{REFERENCES}

1. J. E. Mende1, "The Scientific Basis for Long-Term Prediction of Waste-Form Performance Under Repository Conditions," D. G. Brookins (ed), Sci. Basis for Nuclear Waste Management, VI, Elsevier, Publ. Co., New York, pp 1-7, 1983.

2. G. K. Jacobs and M. J. Apted, "Eh-pH Conditions for Groundwater at the Hanford Site, Washington: Implications for Radio-nuclide Solubility in a Nuclear Waste Repository Located in Basalt, "EOS Trans. Amer. Geophys. Union, 62, p 1065, 1981.

3. D. M. Strachan, "Results from a One-Year Leach Test: Long Term Use of MCC-1," W. Lutze (ed.), Sci. Basis for Nuclear Waste Management, $\underline{V}$, Elsevier Publ. Co., New York, pp 181-191, 1982.

4. J. E. Mende 1, "Workshop on the Leaching Mechanisms of Nuclear Waste Forms, May 19-21, 1982 Summary Report," PNL-4382, p 255, 1982.

5. C.M. Jantzen, "Effects of Eh (Oxidation Potential) on Borosilicate Waste Glass Durability," Advances in Ceramics, 8, Nuclear Waste Management, Am. Ceramic Soc, Columbus, OH, pp 3855-393, 1984.

6. C.M. Jantzen, "Methods of Simulating Low Redox Potential (Eh) for a Basalt Repository," G. L. McVay (ed.), Scientific Basis for Nuclear Waste Management, VII, Elsevier Publ.Co., New York, pp 613-621, 1984.

7. Personal communication M. J. Smith, "Reference Grande Ronde Groundwater \#4," October 4, 1983.

8. G. G. Wicks, N. E. Bibler, C. M. Jantzen, and M. J. Plodinec, "Repository Simulation Tests," Presented at 86th Annual Meeting of American Ceramic Society, Pittsburgh, PA, April 1984.

9. Nuclear Waste Materials Handbook Waste Form Test Methods, MCC-1P Static Test, Prepared by Materials Characterization Center, J. E. Mendel, Manager, USDOE Report DOE/TIC-11400 Pacific Northwest Laboratory, Richland, WA, 1981.

10. C. M. Jantzen and M. J. Plodinec, "Thermodynamic Model of Natural, Medieval, and Nuclear Waste Glass Durability," J. Non-Crystalline Solids, 67, [1-3], pp 207-223, 1984.

11. T. 0. Early, D. R. Drewes, and G. K. Jacobs, "Geochemical Controls on Radionuclide Releases from a Nuclear Waste Repository in Basalt, Estimated Solubilities for Selected Elements," in Geochemical Behavior of Disposed Radioactive Waste, ACS Symp. Series 246, pp 147-166, 1984. 
CC: E. L. Bowser, DOE-SR

D. L. McIntosh, SRP

J. T. Lowe - W. R. Stevens, SRL

R. B. Fergus on

M. J. Plodinec

C. M. Jantzen - G. G. Wicks

$m_{5-3}$ File $(\mathrm{DP}-\mathrm{MS}-84-61)$

November 12,1984

\section{TO DISTRIBUTION}

Attached is a copy of the following:

DP-MS-84-61, "CONTROL OF OXIDATION POTENTIAL FOR BASALT REPOSITORY SIMULATION TESTS", by C. M. Jantzen and G. G. Wicks .

A paper proposed for presentation at the 1984 Annual Materials Research Society Symposium to be held November 26-30, 1984 in Boston, Mass. and for publication in the Proceedings of the symposium.

If any technical clarification is needed please call c. J. Banick.

If there are comments about its release, notify the Records Management Office within 14 days (Ext. 2606).

For any technical clarification, we suggest you call:

R. B. Ferguson, Research Manager Waste Solidification Technology Division Savannah River Laboratory 